Z Badań nad Książką i Księgozbiorami Historycznymi 2019. T. specjalny: Dla Niepodległej The Studies into the History of the Book and Book Collections 2019. Special issue: For an Independent Poland

ISSN 1897-0788, e-ISSN 2544-8730

www.bookhistory.uw.edu.pl

Weronika Pawłowicz

Biblioteka Śląska w Katowicach

weronika.pawlowicz@bs.katowice.pl

ORCID 0000-0002-3502-1376

\title{
„Chciwiec na wydawnictwa z zakresu przyrodoznawstwa". Lwowski nauczyciel Jan Smetański i fragment jego kolekcji w Bibliotece Śląskiej w Katowicach
}

\author{
Abstract \\ "Greedy for books on natural science". Lviv teacher Jan \\ Smetanski and a fragment of his collection in the Silesian \\ Library in Katowice
}

Jan Smetanski (1881-1959), a Lviv natural historian and a high school teacher, was an avid bibliophile. He assembled a rich collection of 40,000 volumes, which was removed from Lviv after the war and located first in Przemysl and then in Katowice. After the owner died, the collection was dispersed. Some of the books were purchased by the Institute of Zoology of the Polish Academy of Sciences in Warsaw, a part by the Silesian Library in Katowice, a fragment of the collection remained in the possession of the family. The article discusses a fragment of Jan Smetanski's collection kept in the collections of the Silesian Library.

Key words: Jan Smetański - Lviv - Katowice - Przemyśl - collections - private collections the Silesian Library in Katowice - bibliophily - book collections.

Słowa kluczowe: Jan Smetański - Lwów - Katowice - Przemyśl - kolekcje - zbiory prywatne - Biblioteka Śląska - bibliofilstwo - księgozbiory.

„Z Badań nad Książką i Księgozbiorami Historycznymi” - Udział zagranicznych recenzentów w ocenie publikacji; Stworzenie anglojęzycznej wersji wydawniczej publikacji; Digitalizacja tomów archiwalnych rocznika w celu zapewnienia otwartego dostępu do nich przez Internet oraz wdrożenie i utrzymanie cyfrowej platformy redakcyjnej - zadanie finansowane w ramach umowy $\mathrm{nr}$ 653/P-DUN/2019 ze środków Ministra Nauki i Szkolnictwa Wyższego przeznaczonych na działalność upowszechniającą naukę. 
Do zbiorów Biblioteki Śląskiej (BŚ) w okresie powojennym trafiło dużo książek o proweniencji kresowej. W literaturze poświęconej książnicy wymieniano też kolekcję lwowskiego profesora Jana Smetańskiego ${ }^{1}$, bliżej jednak nie była ona znana. Podjęte badania źródeł archiwalnych i poszukiwania katalogowo-biblioteczne pozwoliły na zidentyfikowanie w obecnym zasobie Biblioteki książek pochodzących z tego zbioru. Postać kolekcjonera poznano wyzyskując źródła biograficzne ${ }^{2}$ i opracowania historyczne. Nawiązano również kontakt z wnukiem J. Smetańskiego, inżynierem Januszem Guziakiewiczem, który udostępnił kopie dokumentów archiwalnych będących w posiadaniu rodziny i udzielił autorce wielu cennych informacji ${ }^{3}$. Celem niniejszej pracy jest ukazanie życia i działalności lwowskiego bibliofila oraz przybliżenie jego kolekcji.

Jan Smetański urodził się 6 VII 1881 r. w Hołyniu w powiecie Kałusz, w województwie stanisławowskim ${ }^{4}$. Pochodził z rodziny rusińsko-polskiej, wyznania grecko-katolickiego. Był synem nauczyciela szkół ludowych Andrzeja Smetańskiego ${ }^{5}$ i Marii z Kilarskich ${ }^{6}$. Jan uczęszczał do szkoły w Hołyniu $^{7}$, następnie do gimnazjum w Stanisławowie, a potem we Lwowie. Maturę zdał w 1901 r. Podjął następnie studia przyrodnicze na Wydziale Filozoficznym Uniwersytetu w Pradze (1901-1902), a po pierwszym semestrze przeniósł się na Uniwersytet Jana Kazimierza we Lwowie (1902-1906). Głównym przedmiotem jego nauki była historia naturalna, ponadto specjalizował się w geologii, fizyce i matematyce. Studia ukończył z wynikiem celującym.

1 Zob. Biblioteka Ślaska 1922-1972, pod red. J. Kantyki, Katowice 1972, s. 97.

2 Zob. J. Mayer, Smetański Jan, [w:] SKPK, s. 832-833; [J. Felisiakówna] J.F., Smetański Jan, [w:] Stownik biologów polskich, red. S. Felisiak, Warszawa 1987, s. 494; C. Majorek, Smetański Jan (1881-1959), [w:] PSB, Warszawa 1999-2000, t. 39, s. 203.

3 W tym miejscu Autorka chce wyrazić swoje podziękowania panu J. Guziakiewiczowi za informacje i udostępnienie materiałów.

${ }^{4}$ Archiwum Rodziny Smetańskich (dalej: ARS), Dokumenty J. Smetańskiego. S'vìdoctvo urodin ì hreŝenâ. Testimonium ortus et baptismi.

5 Syn Jakuba Śmietańskiego i Julianny Wiwyniak (?), ur. 18 XII 1843 r. w Kałuszu. W dokumentach pojawiają się dwie formy nazwiska: Smetański i Śmietański, zob. ARS, Dokumenty A. Smetańskiego. Testimonium Baptismi.

6 Córka Michała Kilarskiego i Magdaleny z Tyczyńskich, ur. 16 I 1847 r. w Dolinie, zob. ARS, Dokumenty M. Kilarskiej. Testimonium Baptismi.

7 Na świadectwie z kl. III widnieje podpis A. Smetańskiego jako nauczyciela. 
25 XI 1905 r. Jan Smetański ożenił się z Józefą Zacharyasiewicz, z lwowskiego rodu ormiańskiego ${ }^{8}$. Ślub odbył się w greckokatolickiej Cerkwii Wołoskiej we Lwowie. W 1906 r. urodziła się córka Irena9 ${ }^{9}$ a trzy lata później syn Roman $^{10}$.

Jan, podobnie jak ojciec, został nauczycielem. Pracował w szkołach z polskim i ruskim językiem wykładowym, pokonując kolejne stopnie kariery: był zastępcą nauczyciela, egzaminowanym zastępcą nauczyciela ${ }^{11}$, a następnie nauczycielem gimnazjalnym (profesorem). Uczył historii naturalnej, matematyki i fizyki w gimnazjach w Kołomyi (1906-1907), we Lwowie (19071935), w Przemyślu (1912-1913) ${ }^{12}$. W czasie I wojny światowej pracował jako nauczyciel w Brnie (1914-1916).

Zachowane dokumenty, spisy nauczycieli oraz sprawozdania szkolne wymieniają Smetańskiego wśród grona pedagogicznego gimnazjum z ruskim językiem wykładowym w Przemyślu, filii Gimnazjum Akademickiego z ruskim językiem wykładowym we Lwowie ${ }^{13}$, II Państwowego Gimnazjum im. Karola Szajnochy ${ }^{14}$, prywatnego gimnazjum realnego z niemieckim językiem wykła-

8 Józefa Olga Zacharyasiewicz (1881-1946), córka Waleriana i Adeli, zob. ARS, Dokumenty J. Smetańskiego. Svìdoctvo vìnčannâ. Testimonium copulationis.

9 I. Smetańska (1906-1999). Dnia 15 VI 1929 r. w katedrze ormiańskiej we Lwowie poślubiła pracownika kolei inż. Józefa Guziakiewicza (1903-1975). W październiku 1945 r. wraz z rodziną opuściła Lwów, osiadła w Katowicach. Syn Janusz pracował na Politechnice Śląskiej, mieszka obecnie w Pyskowicach, zob. ARS, Zawiadomienie o ślubie I. Smetańskiej i J. Guziakiewicza. Informacje J. Guziakiewicza.

10 R. Smetański (1909-1992). W 1929 r. zdał maturę w VII Państwowym Gimnazjum im. Tadeusza Kościuszki. Ukończył studia na Wydziale Rolniczo-Lasowym Politechniki Lwowskiej, pracował następnie w Lwowskiej Izbie Rolniczej. W 1944 r. był docentem w Politechnice Lwowskiej, w Katedrze i Instytucie Technologii Rolniczej w Dublanach. 11 X 1945 r. ożenił się z Barbarą Bernaś (ur. 1914), absolwentką Wyższej Szkoły Handlu Zagranicznego we Lwowie. W październiku 1945 r. opuścił Lwów. Od władz Lwowskiego Instytutu Politechnicznego uzyskał pozwolenie na wywiezienie swojej liczącej 1000 tomów biblioteki naukowej. Mieszkał w Przemyślu, a potem w Szczecinie i Wrocławiu. Pracował naukowo, w 1968 r. uzyskał stopień doktora. Wydał kilka prac z zakresu przetwórstwa mleka. Zob. ARS, Dokumenty R. Smetańskiego, m.in. Testimonium Baptismi, indeks Politechniki Lwowskiej, legitymacje pracownicze, Spravka (pozwolenie na wywóz biblioteki), Karta ewakuacyjna, Odpis dyplomu doktorskiego. Informacje J. Guziakiewicza.

11 ARS, Dokumenty J. Smetańskiego. Świadectwo egzaminu na nauczyciela. Lwów, 11 VI 1912.

12 Historia naturalna $[\ldots]$, ,Kalendarzyk Profesorski Tow. Naucz. Szkół Wyższych na rok...” 1913, s. 187, Przemyśl, „Kalendarzyk Profesorski Tow. Naucz. Szkół Wyższych na rok...” 1913, s. 249 - Gimnazjum ruskie w Przemyślu.

${ }^{13}$ „Zvìt direkciï c.k. akademičnoï gìmnaziï u L'vovì za škil'nij rìk 1915/1916”, II, Urâdova čast', s. 12 w filii Gimnazjum Akademickiego uczył matematyki, historii przyrody, fizyki, a także języka polskiego. „Zvì direkciï akademičnoï gìmnaziï u L’vovì za škil'nij rìk 1920/1921”, s. 6 - uczył matematyki, historii przyrody, robót ręcznych (także w placówce głównej, tamże s. 5), prowadził kursy introligatorstwa.

14 „Sprawozdanie Dyrekcji Państwowego Gimnazjum II Im. K. Szajnochy we Lwowie za rok szk. 1920/1921”, s. 5 - wymienia Smetańskiego jako nauczyciela etatowego filii I gimnazjum, w szkole tej uczył 10 godzin tygodniowo. „Sprawozdanie ... za rok 1928/29”, s. 2, 3 - w gronie 
dowym prowadzonego przez ewangelicką gminę wyznaniową, prywatnego żeńskiego gimnazjum dr Adeli Karpówny ${ }^{15}$. Nauczał także w III Gimnazjum im. Króla Stefana Batorego, w którym zorganizował kółko przyrodnicze dla uczniów klas II-VIII i był redaktorem odpowiedzialnym pisma „Młody Biolog. Czasopismo dla miłośników biologii”, wydawanego przez członków tego kółka (1932, ukazały się dwa zeszyty) ${ }^{16}$. Z dniem 31 VII 1934 r. Smetański przeniesiony został $\mathrm{w}$ stan spoczynku ${ }^{17}$.

Nie zachowały się dokumenty dotyczące jego dalszego zatrudnienia. Prawdopodobnie przez jakiś czas nie pracował, i dopiero w maju 1937 r. objął stanowisko kustosza Muzeum Instytutu Stauropigialnego we Lwowie ${ }^{18}$. Już w czerwcu tego roku, obok seniora Instytutu Antoniego Gułły ${ }^{19}$, uczestniczył w XIII Zjeździe Związku Muzeów w Polsce ${ }^{20}$. Artykuł Smetańskiego o Muzeum został zamieszczony w tomie prac wydanym z okazji 350-lecia

nauczycieli gimnazjum, 16 godzin tygodniowo. Opiekował się także kółkiem przyrodniczym założonym w roku szkolnym 1926/27 z bogatą biblioteką i zbiorami przyrodniczymi, które organizowało wycieczki, wykłady, naukę fotografowania. Zob. tamże, s. 9-10.

${ }_{15}$ Spis nauczycieli szkót wyższych, średnich, zawodowych, seminariów nauczycielskich oraz wykaz zakładów naukowych $i$ władz szkolnych, zest. pod red. Z. Zagórowskiego, Lwów-Warszawa 1924, s. 307, 311, 313, 317.

16 „Młody Biolog. Czasopismo dla miłośników biologii” 1933, z. 1-2, [online] https://polona. $\mathrm{pl} /$ item/mlody-biolog-czasopismo-milosnikow-biologii-wydawnictwo-kolka-przyrodniczego-iii,NjYwNzI2ODI/2/\#info:metadata [dostęp 20.09.2019]; Zeszyt 2 miał podtytuł: „Szkice przyrodnicze dla miłośników biologii”, [online] https://polona.pl/item/mlody-biolog-czasopismo-milosnikow-biologii-wydawnictwo-kolka-przyrodniczego-iii,NjYwNzI2ODY/2/\#info:metadata [dostęp 20.09. 2019].

17 ARS, Dokumenty J. Smetańskiego. Odwołanie od decyzji Kuratorium Okręgu Szkolnego Lwowskiego.

18 Zob. Personalia, ,Komunikat nr ... [Związku Muzeów w Polsce]” 1937, nr 27, s. 4: „Dr Adrian Kopystański, dotychezasowy kustosz Muzeum Stauropigiańskiego we Lwowie ustąpił w dniu 9 b.m. z zajmowanego stanowiska, które objął nowy kustosz Jan Smetański”. Muzeum Instytutu Stauropigialnego istniało od 1889 do 1939 r. W latach 1933-1939 było członkiem Związku Muzeów w Polsce. Zob. E. Chwalewik, Muzeum Stauropigijne, [w:] Zbiory polskie. Archiwa, biblioteki, gabinety, galerie, muzea i inne zbiory pamiątek przeszłości $w$ ojczyźnie $i$ na obczyźnie w porządku alfabetycznym wedtug miejscowości ułożone. T. 1: A-M, Warszawa-Kraków 1926, s. 409-410; B. Mansfeld, Muzea na drodze do samoorganizacji. Zwiazek Muzeów w Polsce 1914-1951, Warszawa 2000, s. 145; O.S. Kiričuk, L.D. Fedorova, Muzej Stavropigìjs 'kogo Institutu u L'vovì, [w:] Enciklopediâ istorï Ukrä̈ni. T. 7: Ml-O, Kiïv 2010, s. 112-113 [online], http://history.org.ua/LiberUA/978-966-00-1061-1/978-966-00-1061-1.pdf [dostęp 20.10.2018].

19 Antoni Osipowicz Gułła (ur. 1874), prawnik, od 1929 r. członek Instytutu Stauropigialnego, od 1930 jego senior. Zob. V.R. Vavrik, Členy Stavropigiona za 350 lět, [w:] Úbilejnyj S'bornik" v" pamât' 350-letiâ L'vovskago Stavropigiona. Cz. 2: Vremennik". Naučno-literaturnyâ zapiski l'vovskago Stavropigiona na 1936 i 1937 gody, red. V.R. Vavrik, L'vov' 1937, s. 134, [online], https:// vk.com/doc399489626_449126777 [dostęp 20.072018].

20 Zob. Protokót XIII Zjazdu Delegatów „Zwiąku Muzeów w Polsce”, odbytego we Lwowie i Podhorcach w dniach 12-14 czerwca 1937 r., „Pamiętnik Muzealny” 1938, z. 7, s. 3; B. Mansfeld, Muzea na drodze do samoorganizacji..., s. 152. 
Instytutu Stauropigialnego ${ }^{21}$. Był aktywnym działaczem Instytutu - İvan' Andeevič' Smetanskìj, nauczyciel gimnazjalny, został przyjęty 4 VI 1924 r., w latach 1936-1937 należał do Rady Instytutu, był prefektem Muzeum i Bursy ${ }^{22}$. Uczestniczył też w obchodach jubileuszowych w dniu 16 IV 1936 r. ${ }^{23}$

Smetański angażował się w działalność także innych stowarzyszeń. Należał do Polskiego Towarzystwa Przyrodników im. Kopernika ${ }^{24}$. Uczestniczył w XV Zjeździe Lekarzy i Przyrodników Polskich w lipcu 1937 r. we Lwo$w_{i e}^{25}$. Podczas zjazdu odbyło się zebranie organizacyjne oddziału lwowskiego Ligi Ochrony Przyrody, został wówczas powołany do komisji rewizyjnej ${ }^{26}$. Był aktywnym członkiem Małopolskiego Towarzystwa Ogrodniczego - pracował w jego Wydziale ${ }^{27}$, a w 1937 r. został jednym z wiceprezesów ${ }^{28}$. $\mathrm{Na}$ spotkaniach Towarzystwa wygłaszał referaty ${ }^{29}$, publikował artykuły o ogrodnictwie w piśmie „Bartnik Postępowy”, w „Dziale Ogrodniczo-Sadowniczym" (za który był też odpowiedzialny) ${ }^{30}$. Współpracował z radiem lwowskim - jego pogadanka „Babie Lato” wymieniona jest w programie radiowym na 7 X $1934^{31}$.

Był też autorem kilku publikacji książkowych poświęconych problematyce przyrodniczej. W 1922 r. opracował na nowo i uporządkował ukraiński

21 I.A. Smetanskij, Muzej Stavropigìjskago Instituta, [w:] Ûbilejnyj S'bornik”..., s. 52-53.

22 Zob. V.R. Vavrik', Členy Stavropigiona..., s. 121 ; Pravâsij Sovět, [w:] Ûbilejnyj S'bornik”..., s. 143. Fot. zarządu zob. tamże, po s. 113.

${ }^{23}$ 'Fomino voskresenie 1936 goda, [w:] Ûbilejnyj S'bornik"..., s. 10.

24 Zob. Spis członków Polskiego Towarzystwa Przyrodników Polskich im. Kopernika wedtug stanu z dnia 1 września 1936 r., „Kosmos. Czasopismo Polskiego Towarzystwa Przyrodników im. Kopernika" Seria B, 1936, nr 4, s. 319.

25 Zob. Lista uczestników, „Dziennik XV Zjazdu Lekarzy i Przyrodników Polskich we Lwowie", 6 VII 1937, nr 4, s. 10 (poz. 1321).

26 Zob. Zebrania, „Chwila. Dziennik dla spraw politycznych, społecznych i kulturalnych” 1937, $\operatorname{nr} 6572$ (7 VII), s. 10.

27 Wydział - zarząd, komitet zarządzający. Określenie używane w Galicji, a także na Śląsku. Zob. Słownik języka polskiego. T. 7: T-Y, pod red. J. Karłowicza, A. Kryńskiego, W. Niedźwiedzkiego, Warszawa 1919, s. 849.

28 Zob. Zdjęcie fotograficzne Wydziatu M.T.O. w dniu 7 II 1937, „Bartnik Postępowy. Pismo poświęcone pszczelnictwu i ogrodnictwu” 1937, nr 2, s. 58 (dalej: „Bartnik Postępowy”). Informacja o wyborze Wydziału na Walnym Zebraniu 14 II 1937 r. zob. Z życia Małopolskiego Towarzystwa Ogrodniczego, „Bartnik Postępowy” 1937 nr 3, s. 92.

29 M.in. 9 II 1936 r. „O liściu od kolebki do śmierci swojej”, a 25 V 1936 „Zielony darmozjad w naszych parkach i ogrodach” (zob. Z życia Małop. Tow. Ogrodniczego [...], „Bartnik Postępowy” 1936 nr 3, s. 96; Zżycia Małopolskiego Towarzystwa Ogrodniczego [...], „Bartnik Postępowy” 1936, nr 6, s. 204).

30 „Bartnik Postępowy. Pismo poświęcone pszczelnictwu i ogrodnictwu” ukazywał się od 1875 r. Zob. Najstarsze polskie czasopisma ogrodnicze, „Bartnik Postępowy” 1936, nr 5, s. 164.

31 Lwów, „Fala. Programy Polskiego Radia” 1934, nr 1 (4 X), s. 2. W radiu wystąpił też syn Jana, inż. R. Smetański, który 5 VIII 1937 r. wygłosił pogadankę „Jakie korzyści daje ustawa mleczarska”. Zob. Programy Lokalne. Lwów, „Antena. Ilustrowany tygodnik dla wszystkich” 1937, nr 31 (1 VIII), s. XVIII. 
podręcznik botaniki autorstwa Ivana Verhratskiego, zawierający łacińsko-ukraiński indeks nazw roślin ${ }^{32}$. Wspólnie z Janem Wójcikiem opublikował książkę O czem posiadacz ogródka dziatkowego wiedzieć powinien? ${ }^{33}$, z bogatą bibliografią dotyczącą m.in. pszczelarstwa, jedwabnictwa, hodowli zwierząt futerkowych, zielarstwa (odnotowano 617 poz. od 1549 r.). „Z okazji wystawy rybackiej urządzonej przez Izbę rolniczą we Lwowie w czasie XV Targów Wschodnich" wydał bibliografię, która wykazała 588 dzieł poświęconych rybom i rybołówstwu ${ }^{34}$. W następnej publikacji przedstawił lwowskie parki i skwery, a kolejnych kilka prac poświęcił zagadnieniom historii towarzystw ogrodniczych i prasy z tego zakresu oraz ziołom i ziołolecznictwu ${ }^{35}$.

J. Smetański był zapalonym bibliofilem i właścicielem bogatego księgozbioru. Od 1925 r. należał do Towarzystwa Miłośników Książki we Lwowie ${ }^{36}$. Tak wspomina go w swojej książce Mieczysław Opałek: w antykwariacie Marka Hölzla „myszkował cierpliwie nauczyciel gimnazjalny Jan Smetański, nie zaspokojony nigdy chciwiec na wydawnictwa z zakresu przyrodoznawstwa"37.

Główną część jego kolekcji stanowiły książki związane z problematyką przyrodniczą. Edward Chwalewik w 1927 r. pisał:

Biblioteka przyrodniczo-myśliwska, gromadzona z pietyzmem od lat 25-ciu, ponoć największa w danym zakresie w Małopolsce Wschodniej. Liczy około 5000 dzieł, zarówno dawnych, jak i nowszych, głównie w języku polskim z zakresu zoologii ogólnej, botaniki, geologii, entomologii, paleontologii, myśliwstwa, pszczelnictwa, ornitologii, mykologii itd. Posiada własny exlibris ${ }^{38}$.

32 I. Verhradskij, Botanika na nizš̀i klâsi serednih škil, wyd. 2, oprac. J. Smetański, L'vìv 1922.

33 J. Wójcik, J. Smetański, O czem posiadacz ogródka dziatkowego wiedzieć powinien? (praca zbiorowa i bibliografia), Lwów 1934.

34 J. Smetański, Zarys polskiej bibliografii rybackiej, Lwów 1935. Autor odnotował tutaj 18 pozycji z XVI-XVII w. oraz dzieła z XIX i XX w. w 17 działach, m.in. o gatunkach ryb, ich hodowli, chorobach, gatunkach żyjących w wybranych rzekach Małopolski (m.in. w Bystrzycy, Czeremoszu, Dniestrze, Zbruczu, Narwi, Wiśle), rybach morskich, rybołówstwie i użytkowaniu ryb. Trzy pozycje wymieniał w dziale „Ryba w poezji i humoresce-noweli”, a ostatni dział ujmował prace o raku.

35 Są to następujące publikacje J. Smetańskiego: Zieleń we Lwowie, Lwów 1936; Lwowskie pierwsze Towarzystwo Ogrodnicze (jego działalność, gospodarka ogrodowa i szkoła ogrodnicza), Lwów 1938; Małopolskie Towarzystwo Ogrodnicze we Lwowie (jego historia i sprawozdanie ogólne z działalności za rok 1935), Lwów 1936; Małopolskie Towarzystwo Ogrodnicze we Lwowie, Lwów 1937 (z historią organizacji i sprawozdaniem z jego działalności za 1936 r.); Przyczynek do dziejów ogrodnictwa lwowskiego (towarzystwa i czasopisma ogrodnicze), Lwów 1937; Apteczka roślinna, Lwów 1938.

36 Zob. Towarzystwo Miłośników Ksiażki we Lwowie w marcu 1925, [b.m.] 1925, s. 6; Poczet członków Polskich Towarzystw Bibliofilskich wr. 1926, Warszawa 1926, s. 16; Poczet członków Polskich Towarzystw Bibliofilskich w r. 1928, Warszawa 1928, s. 23.

37 M. Opałek, Ze wspomnień lwowskiego bibliofila, Rzeszów 2001, s. 148.

38 E. Chwalewik, Smetański Jan, [w:] tegoż, Zbiory polskie.... T. 2: $N$-Ż, Warszawa-Kraków 1927, s. 553. 
W późniejszych źródłach wielkość zbioru oceniana jest na 30000 do nawet 40000 woluminów ${ }^{39}$. Książki zgromadzone były w mieszkaniu przy ul. Głowińskiego 14, umieszczone w przeszklonych szafach. Na tym zbiorze bazował przygotowując swoje publikacje, z niego czerpał do nich ilustracje.

Wspomniany przez Chwalewika ekslibris wykonany był przez J. Ignatowskiego techniką cynkotypii. Przedstawiał otwartą książkę, w której na jednej stronie widniały słowa „Ex Libris” i sowa w łódce, na drugiej umieszczono zapis: „Prf. Jana Smetańskiego we Lwowie”. Twórca popełnił błąd w zapisie nazwiska „Śmietański”, powstała więc wersja druga, poprawna ${ }^{40}$. Jednak pomimo skorygowania treści, Smetański z rzadka umieszczał księgoznak na posiadanych tomach ${ }^{41}$. Nie nanosił również na książki żadnych not własnościowych ani pieczątek.

Ten bogaty księgozbiór, różnorodny pod względem tematycznym, wielojęzyczny, obejmujący rękopisy, stare druki, grafikę, kartografię, czasopisma, a także druki ulotne, narastał do września 1939 r. i później, jak wskazują zachowane na tomach znaki proweniencyjne oraz spisy książek.

Nie wiadomo dokładnie, czy i gdzie pracował J. Smetański w czasie wojny. Czesław Majorek przypuszczał, że utrzymywał się on z doradztwa ogrodniczego i zielarskiego ${ }^{42}$. Maciej Matwijów wymienia J. Smetańskiego jako komisarycznego zarządcę Biblioteki Gubernialnej (Obwodowej), mianowanego na to stanowisko w lipcu 1941 r. przez Gustawa Abba, dyrektora Głównego Zarządu Bibliotek w Generalnym Gubernatorstwie ${ }^{43}$.

Jesienią 1945 r. dzieci Smetańskiego wraz z rodzinami opuściły Lwów. On sam z żoną również mieli wyjechać, ale Józefa chorowała na astmę, wyjechać nie mogła i zmarła w maju 1946 r. ${ }^{44}$ Po jej śmierci Jan został we Lwowie sam. 22 VI 1946 r. w liście do syna pisał:

39 Zob. K. Maleczyńska, Książki i biblioteki w Polsce okresu zaborów, Wrocław 1987, s. 211 (40 000 t.); J. Szocki, Księgozbiory domowe inteligencji i ziemian w Galicji (1795-1914), „Z Badań nad Polskimi Księgozbiorami Historycznymi” 1996, t. 17, s. 104; Biblioteki na wschodnich ziemiach II Rzeczypospolitej. Informator, red. nauk. B. Bieńkowska, oprac. U. Paszkiewicz i in., Poznań 1998, s. 373 (1939: 30000 tomów).

40 Zob. Ł. Jastrząb, Inwentarz ekslibrisów Biblioteki Kórnickiej. Z. 1: Sygnatury 1-2310, Kórnik 2014. Wersja 1 (5,3x6,4 cm): Ex 1754, Ex 1846, Ex 296; wersja 2 (8,1x8,8 cm): Ex 1753.

${ }^{41}$ Informacje J. Guziakiewicza. W Bibliotece Śląskiej ekslibris został odnaleziony tylko na jednym woluminie.

42 Zob. C. Majorek, Smetański Jan.... Być może utrzymywał się z korepetycji. Mogą o tym świadczyć podręczniki do nauki biologii, niemiecki z 1940 r. i rosyjski z 1941, zachowane w jego zbiorach (w posiadaniu rodziny). Zob. Spisy lwowskiej kolekcji książek Jana Smetańskiego [dwa bruliony] oraz list jego córki Ireny Guziakiewicz do Biblioteki Śląskiej w Katowicach [rękopis]. Biblioteka Śląska (dalej: BŚL), R 2991 III, z. 1, k. 56 v., pudło 43; k. 63 v., pudło 47.

43 M. Matwijów, Zakład Narodowy imienia Ossolińskich w latach 1939-1946, Wrocław 2003, s. $115-116$.

44 ARS, Dokumenty J. Smetańskiego. Karta ewakuacyjna. Świadectwo śmierci J. Smetańskiej. 
Ja likwiduję mieszkanie [...]. Czuję się bardzo a bardzo złamany, opuszczony, mam dużo a dużo przykrości, a wiedz, że sam jestem, wszyscy wyjechali tak, że nie mam do kogo przemówić, absolutnie nie ma nikogo już we Lwowie. Chodzę codziennie na grób i to jedynie moje zajęcie i pakuję się. W dodatku mieszkanie chcą zająć Sowieci i stąd walka ${ }^{45}$.

Informował, że wyjedzie ,z transportem politechnicznym”. Zabierał bibliotekę, prosił więc: „Przygotuj mi miejsce na złożenie książek, około $15 \mathrm{~m}^{3 "}$. Lwów opuścił z trzecim, ostatnim transportem profesorów Politechniki Lwowskiej $^{47}$. Wywoził 20 przedmiotów użytku domowego i bibliotekę ${ }^{48}$. Osiadł w Przemyślu, w mieście, w którym „czuć lwowskie powietrze”49. Ponownie podjął pracę jako nauczyciel przedmiotów matematyczno-przyrodniczych w Liceum Ogólnokształcącym im. Juliusza Słowackiego oraz w Liceum Pedagogicznym $^{50}$. W 1951 r. powtórnie się ożenił ${ }^{51}$. W wolnych chwilach usiłował katalogować swój księgozbiór. Działał też w Towarzystwie Przyjaciół Nauk w Przemyślu, był członkiem jego zarządu ${ }^{52}$. Pracował zawodowo dosłownie do końca życia - zmarł 16 VI 1959 r., w szkole, po konferencji pedagogicznej. J. Smetański, ,zasłużony badacz przyrody ojczystej, doświadczony pedagog i bibliofil", pochowany został na cmentarzu głównym w Przemyślu ${ }^{53}$.

Po śmierci Smetańskiego jego kolekcja uległa podzieleniu i rozproszeniu. Niektóre książki wziął syn do Wrocławia, potem do Szczecina, część postanowiono sprzedać do bibliotek. Władze miejskie Przemyśla pozwoliły rodzinie zatrzymać dłużej mieszkanie i tam pracownicy BŚ oraz Biblioteki Instytutu Zoologicznego Polskiej Akademii Nauk w Warszawie przejrzeli zbiory. Wybrali dzieła przydatne dla tych instytucji. Pozostałe książki zostały spakowane w pudła i przewiezione do córki Ireny, do jej nowo wybudowanego domu w Katowicach Brynowie.

Do Warszawy trafiły prace z dziedziny zoologii, dotyczące hodowli zwierząt, pszczelnictwa, książki popularne przeznaczone dla młodego czytelnika,

\footnotetext{
45 ARS, Dokumenty J. Smetańskiego. List do syna.

46 Tamże.

47 Zob. M. Matwijów, Walka o lwowskie dobra kultury w latach 1945-1948, Wrocław 1996,
} s. 126. Trzecia, ostatnia grupa zwolnionych z Donbasu profesorów Politechniki Lwowskiej i ich rodzin oraz rodzin profesorów pozostałych uczelni lwowskich, skompletowana przez profesora Roberta Szewalskiego, pod opieką profesora Włodzimierza Burzyńskiego opuściła Lwów w czerwcu 1946 r. Zob. Z. Popławski, Dzieje Politechniki Lwowskiej 1844-1945, Wrocław 1992, s. 299-300; Politechnika Lwowska 1844-1945, [kom. red. J. Boberski i in.], Wrocław 1993, s. 68.

48 ARS, Dokumenty J. Smetańskiego. Karta ewakuacyjna.

49 Wspomnienie J. Guziakiewicza, Pyskowice, 21 II 2018. Własność autorki.

50 Zob. E. Kołek, Liceum Pedagogiczne w Przemyślu 1944-1962, „Rocznik Przemyski” 1975, t. 15-16, s. 530. J. Smetański został wymieniony wśród nauczycieli pracujących w latach 1944-1962.

51 Informacje rodziny.

52 Zob. ARS, Nekrolog J. Smetańskiego podpisany przez Zarząd Towarzystwa Przyjaciół Nauk w Przemyślu.

53 Tamże. 
a także publikacje autorstwa Smetańskiego ${ }^{54}$. W „Sprawozdaniu z działalności Instytutu Zoologicznego PAN za rok 1961" odnotowano ,zakup wydawnictw po prof. Smetańskim obejmujący 1460 wol. wydawnictw zwartych i 468 wol. wydawnictw ciągłych" 55 .

Inny fragment księgozbioru nabyła BŚ w Katowicach. Pierwszy wolumin ${ }^{56}$ trafił do książnicy już we wrześniu 1959 r., a kolejne partie w latach 1960$1975^{57}$. Ogółem od I. Guziakiewicz w 44 transzach zakupiono około 2500 dzieł - 18 rękopisów, 84 starych druków, książki, czasopisma, mapy, grafiki, ulotki, druki muzyczne. Są to dzieła głównie w języku polskim, ale również niemieckie, rosyjskie ${ }^{58}$, włoskie, łacińskie. Na książkach zakupionych w latach 60. na odwrocie strony tytułowej zapisywano nazwisko osoby sprzedającejI. Guziakiewicz, później już tylko numer akcesyjny. Trudno więc te woluminy odszukać w ogólnym zbiorze Biblioteki i powiązać z osobą kolekcjonera, który też nie podpisywał posiadanych tomów.

Do najcenniejszych nabytych przez BŚ zbiorów należą rękopisy. Najważniejszym z nich jest szesnastowieczny Oktoich $^{59}$. Wśród pozostałych są opracowania prawnicze, a także teksty literackie, jak egzemplarz teatralny sztuki Georga Friedricha Belly, odpisy utworów i notatki z lektur ${ }^{60}$.

Najstarszym spośród 84 zakupionych z kolekcji Smetańskiego starych druków jest Mariale Bernarda de Bustis, wydane w Strasburgu w 1498 r. $^{61}$ Wśród poloników z XVI w. wyróżnia się lwowski Apostot, drukowany przez

54 Informacja Moniki Malcher, pracowniczki Biblioteki Instytutu Zoologicznego przekazana 19 II $2018 \mathrm{r}$.

55 Archiwum Muzeum i Instytutu Zoologii PAN (dalej: AMilZ PAN), Teczka nr 5257 (IZ PAN 1/24), Sprawozdanie z działalności Instytutu Zoologicznego Polskiej Akademii Nauk za rok 1961, s. 23. Zob. też. W. Laszczykowska, Zarys rozwoju Biblioteki Instytutu Zoologicznego Polskiej Akademii Nauk, Wrocław-Warszawa-Kraków 1965, s. 61: „1928 woluminów zakupionych jednorazowo w r. 1960 z księgozbioru po prof. J. Smetańskim".

56 Jest to starodruk: Aurea Bulla Caroli IV. Romanorum Imperatoris, [...] Cum notis Georgii Theodori Dietrischs [...], Francofurti: Sumpt. Joh. Wilh. Ammonii \& Wilh. Serlini, Typis Aegidii Vogelii, 1658. BŚL 223428 II; współoprawny z dwoma rękopisami: H. Conring, „Discursus [...] De jure publico in genere, et imprimis e quibus scriptoribus jus publ[ici] Germaniae praecipue sit arcessendum“. In Acad. Julia MDCLIII. [Helmstedt 1653]. BŚL R 509 II; H. Conring, „Animadversiones et Discursus [...] ad tractatum Jacobi Lampadii de Rep. Romano-Germanica”. [Helmsted 1653?]. BŚL R 510 II.

57 Archiwum Biblioteki Śląskiej (dalej: ABŚL), Dokumenty akcesyjne. W 1959 r. - 1 partia, 1960 - 2, $1961-19,1962-10,1963-2,1965-4,1966-1,1971-1,1972-1,1973-1,1975-2$.

58 Np. Robota sil's 'koï Biblioteki. Posibnik dlâ sil's 'kih bibliotekariv, Kiïv 1941.

59 BŚL R 1711 III. Omówienie zob. O. Mitric, Rękopis z okresu panowania Eliasza II z Biblioteki Ślaskiej w Katowicach, „Książnica Śląska” 2016, t. 29, s. 85-95.

${ }_{60}$ G. Belly, Żywy nieboszczyk. Krotochwila w 1 akcie, przekład A. Walewskiego, Lwów 1884. Egz. teatralny ze zbioru Kasyna Lwowskiego. BŚL R 576 II; B. Zaleski, Poezje. Odpis, 1837. BŚL R 581 III; M. Paszkudzka, Wypisy wierszy z różnych autorów, 1839. BŚL R 569 I.

${ }^{61}$ Bernardus de Bustis, Mariale, Strasburg: Martin Flach, 1498. BŚL 235265 III. 
I. Fedorova ${ }^{62}$ oraz Biblia tzw. Brzeska ${ }^{63}$. Nabyto nadto dzieła pisarzy klasycznych (Horacego, Owidiusza), religijne, historyczne, literackie, medyczne, przyrodnicze. Na wymienienie zasługuje nieznany bibliografii Estreichera wariant Myślistwa $z$ ogary ${ }^{64}$.

Z jego zbioru pochodzą też nieliczne grafiki (portrety i widoki, między innymi Lwowa), fotografie, mapy oraz druki ulotne z połowy XIX w. i interesujące lwowskie afisze z okresu II wojny światowej.

Większość nabytych książek wydanych zostało w wieku XIX, mniej w początkach XX w. Tematyka ich jest różnorodna. BŚ gromadzi przede wszystkim dzieła dotyczące Śląska i księgozbiór humanistyczny, toteż z oferty przedstawianej przez I. Guziakiewicz wybierano dzieła głównie z tego zakresu. Zakupiono więc liczne edycje śląskie - publikacje wydane w Cieszynie, Wrocławiu, Mikołowie, Katowicach, a także prace autorów śląskich. Do Biblioteki trafiły liczne cenne i ciekawe edycje dzieł pisarzy polskich. Egzemplarz Marii Antoniego Malczewskiego, wydany w Londynie w $1836 \mathrm{r}^{65}$, jest interesujący dla osób zajmujących się ortografią języka polskiego - w edycji zastosowano zapis bez zmiękczeń poprzez literę „¡", ale kreskowanie nad literami. Szczególnie liczne są edycje dzieł Adama Mickiewicza, zwłaszcza wydania Pana Tade$u s z a, \mathrm{w}$ tym również przekład na język białoruski ${ }^{66}$. Zakupiono dzieła Józefa Ignacego Kraszewskiego, Seweryna Goszczyńskiego, Leopolda Staffa, Marii Pawlikowskiej-Jasnorzewskiej, Wacława Grubińskiego i wielu innych.

Smetański zgromadził bogatą kolekcję lwowianów - druków dotyczących Lwowa i wydanych w tym mieście. Posiadał także dzieła przybliżające inne regiony Polski Wschodniej, obecnie „Ziem Utraconych” - opisy geograficzne i historyczne Ukrainy, Litwy, Polesia, Pokucia. Wiele z nich również znalazło się w zbiorach katowickiej książnicy.

Do zbiorów BŚ trafiło natomiast niewiele książek przyrodniczych. To kilka opracowań autorstwa Smetańskiego, ogólne prace przyrodnicze, nieliczne publikacje związane z rybołówstwem i akwarystyką, ogrodnictwem i pszczelarstwem (z edycją dzieła ks. Jana Dzierżona ${ }^{67}$ ).

62 Apostot, Lwów: Ivan Fedorov, 25 II 1573- 15 II 1574. BŚL 237014 III.

63 Biblia swięta, tho iest Księgi Starego y Nowego Zakonu [...], Brześć Litewski: [Cyprian Bazylik], 1563. BŚL 225090 IV.

64 J. Ostroróg, Myslictwo Z Ogary Jana Hrabie z Ostroga Opalinskiego [sic!] Wojewody Poznanskiego. [Var. B], W Łowiczu: [s.n.], 1797. BŚL 222818 I. Egz. z ekslibrisem Smetańskiego. Dostępne w Śląskiej Bibliotece Cyfrowej (dalej: ŚBC): [online] https://www.sbc.org.pl/dlibra/publication/316299/edition/298955 [dostęp 30.08.2019].

65 A. Malczewski, Marja. Poweść [sic!] ukraińska, W Londyńe [sic!] 1836. BŚL 172950 II.

66 A. Mickiewicz, Pan Tadeusz. Paemat, Kn. 1., piarałazỳŭ z polskaho na biełaruski jazỳk A.J., Lwoŭ 1892. BŚL 172817 II, [online] https://www.sbc.org.pl/dlibra/publication/335278/ edition/316797 [dostęp 30.08.2019].

67 J. Dzierżon, Najnowsze pszczelnictwo oparte na zasadach xiędza Dzierzona z postrzė̇enia- 
Podkreślić należy, że wśród nabytych od rodziny Smetańskiego egzemplarzy wiele jest pięknie wydanych, ilustrowanych, zaliczonych przez bibliotekarzy do cimeliów. Liczne dzieła, zwłaszcza poświęcone Kresom Wschodnim, zostały udostępnione w Śląskiej Bibliotece Cyfrowej.

$\mathrm{Na}$ wielu tomach można odnaleźć znaki własnościowe innych osób, niż kolekcjonera. Są dedykacje od autorów, podpisy i pieczątki. Na przykład na jednej z książek jest nota Zofii Strzałkowskiej, właścicielki szkoły prywatnej we Lwowie, po której dodano pieczątki późniejsze - Szkoły im. Zofii Strzałkowskiej ${ }^{68}$. Natomiast na egzemplarzu XVIII-wiecznego indeksu ksiąg zakazanych $^{69}$ zauważyć można pieczątkę Heleny Dąbczańskiej, znanej lwowskiej kolekcjonerki.

$\mathrm{Na}$ licznych woluminach odnajdujemy znaki funkcjonujących we Lwowie księgarń (m.in. Księgarni Polskiej, Księgarni Literackiej, Księgarni Miłkowskiego działającej we Lwowie, Stanisławowie i Tarnowie), a także Wypożyczalni książek Vita, Książnicy Kasyna i Koła Literacko-Artystycznego, Czytelni Koła Towarzyskiego Młodzieży Handlowej, ukraińskiej biblioteki dla dzieci ${ }^{70}$. Zachowały się też egzemplarze z bibliotek szkolnych. Karty tytułowe niektórych książek są pokryte licznymi pieczątkami wskazującymi na zmiany historyczne - znaki rosyjskiego gimnazjum cesarsko-królewskiego, następnie szkoły polskiej, a często potem zakładu ukraińskiego.

Po przejęciu Lwowa przez władze radzieckie zlikwidowano biblioteki polskie szkolne i publiczne, po surowej kontroli wywożąc na przemiał książki „niebłagonadiożne”. Uległo również zniszczeniu wiele kolekcji prywatnych. W miejsce bibliotek publicznych i prywatnych, na bazie ich księgozbiorów utworzono lwowską bibliotekę obwodową oraz sieć bibliotek rejonowych ${ }^{71}$. Na kartach książek odnajdujemy ślady tych przekształceń. Na przykład na stronie tytułowej dzieła Horacego znajdziemy pieczątki Alojzego Rybickiego, biblioteki Gimnazjum im. Karola Szajnochy we Lwowie, a także stempel „Lvivs'ka Deržavna Oblasna Biblioteka” i umieszczoną na wyklejce kartkę: „Knigu treba povernuti ne piznisze viznaczenogo tut terminu”72. W egzemplarzu dzieła Jana Lemańskiego zachowały się nawet ukraińskie karty kata$\operatorname{logowe}^{73}$. Są też książki z Biblioteki Publicznej Miasta Lwowa, pochodzące

mi Morlotta, Pukla, Nutta, Kuhnta, Khünera itd., tł. H. Witowski, Lwów 1853. BŚL 211298 I.

68 F. Habura, Pan Tadeusz a Iljada, Kraków 1874. BŚL 160049 I.

69 Index librorum prohibitorum SSmi D.N. Benedicti XIV [...] jussu recognitus atque editus, Romae: Ex Typographia Rev. Cameræ Apostolicæ, 1758. BŚL 228873 I.

70 T. Ševčenko, Gajdamaki. Poema, Kiev 1939. BŚL 400620 I.

71 Zob. G. Hryciuk, Polacy we Lwowie 1939-1944. Życie codzienne, Warszawa 2000, s. 107108.

72 Horatius, Qvinti Horatii Flacci Poemata, Scholiis [...] illustrate a Johanne Bond..., Brunsvigae: Typis ac sumptibus Christophori Friderici Zilligeri, 1690. BŚL 222651 I.

73 J. Lemański, Bajki, Warszawa 1902. BŚL 171215 II. 
ze zbioru Mariana Gawalewicza i Zygmunta Drągowskiego, z pieczątkami „Oblasnej” biblioteki. W którymś momencie - być może w trakcie kolejnej selekcji księgozbioru i wywożenia książek na przemiał lub likwidacji bibliotek polskich po wkroczeniu wojsk niemieckich do Lwowa w 1941 r. - wybrane książki z biblioteki miejskiej Smetański włączył do swego zbioru.

W zbiorach rękopiśmiennych BŚ przechowywane są również dwa zeszyty zawierające spisy książek znajdujących się u I. Guziakiewicz, a sporządzone przez jej męża Józefa w latach 1970 i $1972^{74}$. Stanowiły one podstawę wyboru dzieł zakupowanych przez Bibliotekę w latach 1971-1974, o czym świadczą naniesione przy opisach noty bibliotekarzy. Większość jednak z wymienionych tu dzieł pozostała $\mathrm{w}$ zbiorze rodzinnym ${ }^{75}$.

Zestawienia wyszczególniają zawartość ponumerowanych pudeł - tak, jak przyjechały z Przemyśla i częściowo ze Lwowa. Pierwszy spis wymienia 46 numerowanych kartonów (numery od 3 do 55) mieszczących 2606 książek w języku polskim (literatura piękna, religijna, opracowania historyczne, publikacje naukowe, dzieła przyrodnicze, z zakresu medycyny, pszczelarstwa, łowiectwa, katalogi, czasopisma, przewodniki, podręczniki) oraz publikacji obcych (m.in. rosyjskich, ukraińskich, niemieckich, francuskich). Jak Guziakiewicz dodał w „Objaśnieniu” zapisanym na kartce naklejonej na wyklejkę pierwszego zeszytu, w niektórych pudłach złożono również pewną ilość broszur, niespisanych z tytułów. Drugie zestawienie, z 1972 r., objęło kolejnych 18 kartonów (numery od 2 do 124) z 1166 dziełami. Są to głównie publikacje obce (żydowskie, niemieckie, ukraińskie, rosyjskie), a także polskie z literatury, historii, nauk przyrodniczych.

Łącznie oba zeszyty wymieniają 3772 dzieła. Są to w przeważającej większości książki z XIX i początku XX w. (do 1939 r.). Pojawiają się też późniejsze, np. niemiecki podręcznik do biologii (Leipzig 1940), książka autorstwa Józefa Stalina ${ }^{76}$, a także powojenne podręczniki fizyki, algebry, geometrii (z lat 1956-1958) ${ }^{77}$ wskazujące na aktywność zawodową kolekcjonera.

Biblioteka Smetańskiego powstawała przez około 50 lat, od początku ubiegłego wieku, we Lwowie. Rozległość jego zainteresowań - nauczyciela przyrodnika, mineraloga, ogrodnika, bibliofila, pozwoliła mu zebrać dzieła różnorodne tematycznie i językowo. Kolekcjonował dzieła przyrodnicze, historyczne, literackie, ukazujące jego ukochany Lwów i Kresy. Niestety, brak dokumentacji oraz jakichkolwiek zapisów na książkach, nie pozwala

\footnotetext{
74 Spisy lwowskiej kolekcji książek Jana Smetańskiego..., BŚL, R 2991 III.

75 Nie można jednak stwierdzić, czy spisy objęły całość biblioteki J. Smetańskiego zachowaną w posiadaniu rodziny.

76 Stalin o wielkiej wojnie, 1943, pudło 47, s. 62a - książka gruzińska.

77 Najpóźniejszy druk: Geometria elementarna, cz. III, dla kl. X-XI, Warszawa 1958. Zob. Spisy lwowskiej kolekcji Jana Smetańskiego..., z.1, k. 55: pudło 43. BŚL R 2991 III.
} 
nam odtworzyć procesu narastania zbioru. Został on jednak ocalony przed zniszczeniem - nie podzielił losu wielu księgozbiorów polskich powstałych we Lwowie. Kolekcja opuściła Kresy, prawdopodobnie w całości. Trafiła do Przemyśla, a potem, po śmierci swego twórcy, uległa rozproszeniu. Część pozostała w posiadaniu rodziny (w Katowicach, Wrocławiu, Szczecinie). Około 4000 woluminów przechowywanych jest w bibliotekach w Warszawie i w Katowicach. To niewielki fragment zbioru szacowanego przez niektórych badaczy nawet na 40000 tomów. Pozwala on jednak przybliżyć bogactwo i wartość tej bliżej dotąd nieznanej kolekcji.

\section{Bibliografia}

Archiwum Rodziny Smetańskich (ARS)

Dokumenty Andrzeja Smetańskiego.

Dokumenty Marii Kilarskiej.

Dokumenty Jana Smetańskiego.

Dokumenty Romana Smetańskiego.

Archiwum Biblioteki Śląskiej (ABŚL Katowice)

Dokumenty akcesyjne z lat 1959-1975.

Archiwum Muzeum i Instytutu Zoologii PAN (AMiIZ PAN Warszawa)

Teczka nr 5257 (IZ PAN 1/24). Sprawozdanie z działalności Instytutu Zoologicznego Polskiej Akademii Nauk za rok 1961.

Rękopisy

Biblioteka Śląska

Spisy lwowskiej kolekcji książek Jana Smetańskiego [dwa bruliony] oraz list jego córki Ireny Guziakiewicz do Biblioteki Śląskiej w Katowicach. BŚL R 2991 III.

Artykuły z czasopism

Historia naturalna [...], „Kalendarzyk Profesorski Tow. Naucz. Szkół Wyższych na rok..." 1913, s. 187.

Kołek E., Liceum Pedagogiczne w Przemyślu 1944-1962, „Rocznik Przemyski” 1975, t. 15-16, s. 519-534.

Lista uczestników, „Dziennik XV Zjazdu Lekarzy i Przyrodników Polskich we Lwowie”, 6 VII 1937, nr 4, s. 10 (poz. 1321).

Lwów, „Fala. Programy Polskiego Radia” 1934, nr 1 (4 X), s. 2.

Mitric O., Rękopis z okresu panowania Eliasza II z Biblioteki Śląskiej w Katowicach, „Książnica Śląska” 2016, t. 29, s. 85-95. 
Najstarsze polskie czasopisma ogrodnicze, „Bartnik Postępowy” 1936, nr 5, s. 164.

Personalia, „Komunikat nr... [Związku Muzeów w Polsce]” 1937, nr 27, s. 3-4.

Programy Lokalne. Lwów, „Antena. Ilustrowany tygodnik dla wszystkich” 1937, nr 31 (1 VIII), s. XVIII.

Przemyśl, „Kalendarzyk Profesorski Tow. Naucz. Szkół Wyższych na rok...” 1913, s. 249.

Protokót XIII Zjazdu Delegatów „Związu Muzeów w Polsce”, odbytego we Lwowie i Podhorcach w dniach 12-14 czerwca 1937 r., „Pamiętnik Muzealny” 1938, z. 7, s. 3-16.

Spis członków Polskiego Towarzystwa Przyrodników Polskich im. Kopernika wedtug stanu z dnia 1 września 1936 r., „Kosmos. Czasopismo Polskiego Towarzystwa Przyrodników im. Kopernika” Seria B, 1936 nr 4, s. 319.

„Sprawozdanie Dyrekcji Państwowego Gimnazjum II Im. K. Szajnochy we Lwowie za rok szk. 1920/1921", Lwów 1921.

„Sprawozdanie Dyrekcji Państwowego Gimnazjum II Im. K. Szajnochy we Lwowie za rok szk. 1928/1929”, Lwów 1929.

Szocki J., Księgozbiory domowe inteligencji i ziemian w Galicji (1795-1914), „Z Badań nad Polskimi Księgozbiorami Historycznymi” 1996, t. 17, s. 51-123.

Z życia Małop. Tow. Ogrodniczego [...], „Bartnik Postępowy” 1936, nr 3, s. 96.

Z życia Małopolskiego Towarzystwa Ogrodniczego [...], „Bartnik Postępowy”, 1936, nr 6, s. 204

Z życia Małopolski.ego Towarzystwa Ogrodniczego, „Bartnik Postępowy” 1937, nr 3, s. 92.

Zdjęcie fotograficzne Wydziału M.T.O. w dniu 7 II 1937, „Bartnik Postępowy” 1937, nr 2, s. 58.

Zebrania, „Chwila. Dziennik dla spraw politycznych, społecznych i kulturalnych” 1937, nr 6572 (7 VII), s. 10.

„Zvìt direkciï c.k. akademìčnoï gìmnaziï u L’vovì za škìl'nij rìk 1915/1916”, 1916.

„Zvìt direkciï akademičnoï gìmnaziï u L'vovì za škìl'nij rìk 1920/1921”, 1921.

Wydawnictwa zwarte

Biblioteka Śląka 1922-1972, pod red. J. Kantyki, Katowice 1972.

Biblioteki na wschodnich ziemiach II Rzeczypospolitej. Informator, red. nauk. B. Bieńkowska, oprac. U. Paszkiewicz i in., Poznań 1998.

Chwalewik E., Archiwa, biblioteki, gabinety, galerie, muzea i inne zbiory pamiatek przeszłości w ojczyźnie i na obczyźnie w porządku alfabetycznym według miejscowości ułożone. T. 1: A-M, Warszawa-Kraków 1926.

[Felisiakówna J.] J.F., Smetański Jan, [w:] Stownik biologów polskich, red. S. Felisiak, Warszawa 1987, s. 494.

'Fomino voskresenie 1936 goda, [w:] Ûbilejnyj S'bornik” v' pamât'350-letiâ L'vovskago Stavropigiona. Cz. 2: Vremennik'. Naučno-literaturnyâ zapiski l'vovskago Stavropigiona na 1936 i 1937 gody, red. V.R. Vavrik, L'vov' 1937, s. 9-12, [online], https:// vk.com/doc399489626_449126777 [dostęp 20.07.2018]. 
Hryciuk G., Polacy we Lwowie 1939-1944. Życie codzienne, Warszawa 2000.

Jastrząb Ł., Inwentarz ekslibrisów Biblioteki Kórnickiej. Z. 1: Sygnatury 1-2310, Kórnik 2014.

Kiričuk O.S., Fedorova L.D., Muzej Stavropigìjs 'kogo Institutu u L'vovì, [w:] Enciklopediâ istorï Ukraïni. T. 7: Ml-O, Kï̈v 2010, s. 112-113 [online], http://history.org.ua/ LiberUA/978-966-00-1061-1/978-966-00-1061-1.pdf [dostęp 20.10.2018].

Laszczykowska W., Zarys rozwoju Biblioteki Instytutu Zoologicznego Polskiej Akademii Nauk, Wrocław-Warszawa-Kraków 1965.

Majorek C., Smetański Jan (1881-1959), [w:] PSB, Warszawa 1999-2000, t. 39, s. 203.

Maleczyńska K., Książki i biblioteki w Polsce okresu zaborów, Wrocław 1987.

Mansfeld B., Muzea na drodze do samoorganizacji. Związek Muzeów w Polsce 19141951, Warszawa 2000.

Matwijów M., Walka o lwowskie dobra kultury w latach 1945-1948, Wrocław 1996.

Matwijów M., Zakład Narodowy imienia Ossolińskich w latach 1939-1946, Wrocław 2003.

Mayer J., Smetański Jan, [w:] SKPK, s. 832-833.

Opałek M., Ze wspomnień lwowskiego bibliofila, Rzeszów 2001.

Poczet członków Polskich Towarzystw Bibliofilskich w r. 1926, Warszawa 1926.

Poczet członków Polskich Towarzystw Bibliofilskich w r. 1928, Warszawa 1928.

Politechnika Lwowska 1844-1945, [kom. red. J. Boberski i in.], Wrocław 1993.

Popławski Z., Dzieje Politechniki Lwowskiej 1844-1945, Wrocław 1992.

Słownik języka polskiego. T. 7: T-Y, pod red. J. Karłowicza, A. Kryńskiego, W. Niedźwiedzkiego, Warszawa 1919.

Smetanskij I.A., Muzej Stavropigìskago Instituta, [w:] Ûbilejnyj S'bornik" v' pamât' 350-letiâ L'vovskago Stavropigiona. Cz. 2: Vremennik”. Naučno-literaturnyâ zapiski l'vovskago Stavropigiona na 1936 i 1937 gody, red. V.R. Vavrik, L'vov' 1937, s. 5253, [online], https://vk.com/doc399489626_449126777 [dostęp 20.072018].

Smetański J., Apteczka roślinna, Lwów 1938.

Smetański J., Lwowskie pierwsze Towarzystwo Ogrodnicze (jego działalność, gospodarka ogrodowa i szkoła ogrodnicza), Lwów 1938.

Smetański J., Małopolskie Towarzystwo Ogrodnicze we Lwowie (jego historia i sprawozdanie ogólne z działalności za rok 1935), Lwów 1936.

Smetański J., Małopolskie Towarzystwo Ogrodnicze we Lwowie, Lwów 1937.

Smetański J., Przyczynek do dziejów ogrodnictwa lwowskiego (towarzystwa i czasopisma ogrodnicze), Lwów 1937.

Smetański J., Zarys polskiej bibliografii rybackiej, Lwów 1935.

Smetański J., Zieleń we Lwowie, Lwów 1936.

Spis nauczycieli szkót wyższych, średnich, zawodowych, seminariów nauczycielskich oraz wykaz zakładów naukowych $i$ władz szkolnych, zest. pod red. Z. Zagórowskiego, Lwów-Warszawa 1924.

Towarzystwo Miłośników Książki we Lwowie w marcu 1925, [b.m.] 1925. 
Ûbilejnyj S'bornik" v' pamât' 350-letiâ L'vovskago Stavropigiona. Cz. 2: Vremennik”. Naučno-literaturnyâ zapiski l'vovskago Stavropigiona na 1936 i 1937 gody, red. V.R. Vavrik, L’vov' 1937, [online], https://vk.com/doc399489626_449126777 [dostęp 20.07.2018].

Vavrik' V.R., Členy Stavropigiona za 350 lět, [w:] Ûbilejnyj S'bornik" v'pamât'350-letiâ L'vovskago Stavropigiona. Cz. 2: Vremennik'. Naučno-literaturnyâ zapiski l'vovskago Stavropigiona na 1936 i 1937 gody, red. V.R. Vavrik, L'vov' 1937, s. 62-144, [online], https://vk.com/doc399489626_449126777 [dostęp 20.072018].

Verhradskij I., Botanika na nìzši klâsi serednih škil, wyd. 2, oprac. J. Smetański, L'vìv 1922.

Wójcik J., Smetański J., O czem posiadacz ogródka działkowego wiedzieć powinien? (praca zbiorowa i bibliografia), Lwów 1934. 